DI: http:/dx.doi.org/10.21704/pja.v2i1.1126

(C) The authors. Published by Universidad Nacional Agraria La Molina

\title{
Antifungal activity of five chemical and two biological fungicides for the management of Botrytis cinerea, causal agent of Gray Mold in Strawberry
}

\section{Actividad antifúngica de cinco fungicidas químicos y dos biológicos para el manejo de Botrytis cinerea agente causal del Moho Gris en Fresa}

\author{
Llanos, A. ${ }^{1 *}$; Apaza, W. ${ }^{1}$
}

*Corresponding author: alejandro.llanosm@hotmail.com

\begin{abstract}
Gray mold, caused by Botrytis cinerea, is one of the most important plant diseases in Strawberry in Peru. Because of its high variability and its pathogenic characteristics, proper fungicides use is essential to control this disease. The aim of this study was to evaluate the effect of five chemical fungicides: Tryfloxistrobin $(0.0625 \%)$, Pyrimethanil + Fluopyram $(0.1 \%)$, Pyrimethanil (0.1\%), Fenhexamid (0.135\%) and Carbendazim (0.125\%), and two biological fungicides: Bacillus subtilis QST713 (0.75\%) and Bacillus pumilus QST2808 (0.75\%) in laboratory and field conditions. In the laboratory phase, the inhibition of mycelial growth was measured by evaluating diameter growth at 4 DAI $(\mathrm{p} \leq 0.05)$. Furthermore, conidial germination inhibition was evaluated in two different ways. First, one hundred conidia were placed in sterile water with fungicide and evaluated at 24 HAI $(p \leq 0.05)$. Second, the number of CFUs was counted in poisoned PDA medium at 3 DDI. The doses $1 \times 10^{6}$ and 125 conidia/mL were used for each test respectively. The field experiment was in Aucallama, Huaral. Chemical and biological fungicides were sprayed in a strawberry cultivar Aromas. Twelve harvests were done. The results showed that chemical fungicides; Trifloxystrobin, Pyrimethanil + Fluopyram, Pyrimethanil, Fenhexamid and the biological fungicide Bacillus subtilis QST713 had considerable activity against Botrytis cinerea in most of the variables assessed. These results will contribute to the evaluation of the potential of each one of these fungicides for the management of Botrytis cinerea.
\end{abstract}

Keywords. Botrytis cinerea, Gray mold, Fragaria $\mathrm{x}$ annanasa, fungicides, strawberry.

\section{Resumen}

El moho gris, causado por Botrytis cinerea, es una de las enfermedades más importantes de las plantas de fresa en el Perú. Debido a su alta variabilidad y sus características patogénicas, el uso adecuado de fungicidas es esencial para controlar esta enfermedad. El objetivo de este estudio fue evaluar el efecto de cinco fungicidas químicos: Tryfloxistrobin $(0.0625 \%)$, Pyrimethanil + Fluopyram $(0.1 \%)$, Pyrimethanil $(0.1 \%)$, Fenhexamid $(0.135 \%)$ y Carbendazim $(0.125 \%)$ y dos fungicidas biológicos Bacillus subtilis QST713 (0.75\%) y Bacillus pumilus QST2808 (0.75\%) en condiciones de laboratorio y de campo. En la fase de laboratorio, la inhibición del crecimiento micelial se midió evaluando el crecimiento del diámetro a 4 DAI $(\mathrm{p} \leq 0.05)$. Además, la inhibición de la germinación conidial se evaluó de dos maneras diferentes. Primero, se colocaron cien conidios en agua estéril con fungicida y se evaluaron a $24 \mathrm{HAI}(\mathrm{p} \leq 0.05)$. En segundo lugar, el número de UFC se contó en el medio de PDA envenenado a 3 DDI. Las dosis $1 \times 10^{6}$ y 125 conidia/mL se utilizaron para cada prueba respectivamente. El experimento de campo fue en Aucallama, Huaral. Se aplicaron fungicidas químicos y biológicos en un cultivar de fresa Aromas. Se hicieron doce cosechas. Los resultados mostraron que los fungicidas químicos Trifloxystrobin, Pyrimethanil + Fluopyram, Pyrimethanil, Fenhexamid y el fungicida biológico Bacillus subtilis QST713 tuvieron una actividad considerable contra Botrytis cinerea en la mayoría de las variables evaluadas. Estos resultados contribuirán a la evaluación del potencial de cada uno de estos fungicidas para el manejo de Botrytis cinerea.

Palabra clave. Botrytis cinerea, moho gris, Fragaria $\mathrm{x}$ annanasa, fungicidas, fresa.

\section{Introduction}

Strawberry is a fruit with a high content of flavonoids, anthocyanins, and phenolic compounds. This fruit contains vitamins A and C (Cano, 2013). Strawberry is a worldwideproduced crop. Furthermore, it has a high demand due to its fresh consumption. This fruit is widely used for making desserts because its qualities such as color, aromas, and acidity (Chaves and Wang, 2004). Apart from its commercial interest, this crop has a great social value due to the high demand of workers required for its production as well as in post-harvest and in the industry (Cano, 2013).

This crop is susceptible to several pathogens which

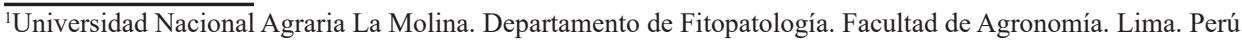


can infect at both levels, field and postharvest. Among the most common diseases are: Anthracnose, caused by the fungus Colletotrichum spp. Leaf spots, caused by Mycosphaerella fragariae; Fruit rot, caused by the fungus Gnomonia co-mari; Powdery mildew, caused by the fungus Sphaerotheca macularis; Wilting, caused by the fungus Fusarium oxysporum; Phytophthora Crown rot (root rot), caused by Phytophthora nicotianae and Fruit rot (Gray mold), caused by the fungus Botrytis cinerea (Koike et al., 2016). The latter is considered the main pathogen because it can infect any state of the plant (Álvarez, 2012).

Botrytis cinerea Pers.: Fr [teleomorph: Botryotinia fuckeliana (de Bary) Whetzel], infects more than 200 different plant species including fruit trees and vegetables. It causes serious economic losses before and after harvesting (Benito et al., 2000; Rebollar 2011). Around 20\% of the world crop is affected by $B$. cinerea causing an investment of billions of euros per year for its control (Genoscope, 2005). There are numerous studies related to this fungus due to the considerable incidence of it and the economic repercussions that have on important crops such as vine, tomato, strawberry, and ornamental crops (Benito et al., 2000).

In strawberry

Table 1. Fungicides evaluated for the control of Botrytis cinerea in the laboratory and field phase

\begin{tabular}{ccccc}
\hline Treatment & Fungicide a.i. & \multicolumn{2}{c}{ Product } & \multicolumn{2}{c}{ FRAC Group* Evaluated dose } \\
\hline 1 & none & Unsprayed Control & none & none \\
2 & Trifloxystrobin & Flint 50 WG & 11 & $0.063 \%$ \\
3 & Pyrimethanil + Fluopyram & Luna Tranquility 500 SC & $9+7$ & $0.100 \%$ \\
4 & Pyrimethanil & Scala 40 SC & 9 & $0.100 \%$ \\
5 & Fenhexamid & Teldor SC & 17 & $0.135 \%$ \\
6 & Bacillus subtilis Strain QST713 & Serenade ASO & 44 & $0.750 \%$ \\
7 & Bacillus pumilus Strain QST2808 & Sonata ASO & - & $0.750 \%$ \\
8 & Carbendazim & Fordazim 5 FW & 1 & $0.125 \%$ \\
\hline
\end{tabular}

c u 1 tivation,

Botrytis cinerea causes large economic losses whose estimates are around $30 \%$ of the total production. In highhumidity conditions, this pathogen could cause economic losses between 40-50\%. Even in post-harvest, it is more aggressive, affecting 95\% of the fruits 48 after harvest (Chaves and Wang, 2004). Infected fruits initially maintain their original shape. At the beginning, the rotten parts are soft and pulpy. Then, a mass of mycelium and gray-brown conidia are produced on the surface, making the fruit to get dry. Direct infection of the fruit can also occur if the fruits are exposed to water film on the surface. These infections develop in the same way as fruits whose flowers were infected. However, these latter infections differ in that multiple initial lesions can a-ppear on any part of the fruit's surface (Koike et al., 2016).

Control of Botrytis cinerea is not easy to manage for several reasons: i) It is capable of attacking crops at any stage of development, even post-harvest, ii) It infects any vegetable organ, iii) It is able to grow at very low storage temperatures, and iv) It is genetic and morphologically heterogeneous organism, which allows it to grow and develop in different crop conditions. Although there are several types of control strategies that play an important role in mitigating the development of this pathogen, traditionally the most used practice has been chemical fungicides
(Espinosa, 2006). Nevertheless, excessive use of these fungicides leads to the development of resistant strains, environmental contamination, and even health problems in humans, leading to a high cost production in the farming industry (Ghorbani et al., 2004; Molina et al. 2006). Currently, the use of biological fungicides has emerged as an important tool for controlling diseases in agriculture.

The aims of this study were: to evaluate the effect of different chemical and biological fungicides in mycelial growth and conidial germination of Botrytis cinerea under in vitro conditions and to measure the effect at fruit level in the harvest under field conditions.

\section{Materials and Methods}

The research was developed in two phases. The first, laboratory phase, consisted of three in vitro tests. The second phase or field phase was carried out in a commercial field evaluating various parameters in the harvest.

\section{Fungicides}

The fungicides evaluated in both phases were: Trifloxystrobin (Flint 75WG, 0.0625\%), Pyrimethanil + Fluopyram (Luna Tranquility 500 SC, 0.1\%), Pyrimethanil (Scala 40 SC, 0.1\%), Fenhexamid (Teldor SC, 0.135\%), Carbendazim (Fordazim 5 FW, 0.125\%), Bacillus subtilis Strain QST713 (Serenade ASO, 0.75\%) and Bacillus pumilus Strain QST2808 (Sonata ASO, 0.75\%). The characteristics of these fungicides are described in Table 1.

\section{Laboratory phase}

This phase was carried out in the Plant Pathology laboratory of the Universidad Nacional Agraria La Molina.

\section{Evaluation in mycelial growth}

Botrytis cinerea was isolated from fruits of Strawberry $\mathrm{cv}$. Aromas that presented typical signs and symptoms in Huaral, Aucallama. This fungus was placed on Papa Dextrose Agar (PDA) and stored at $25^{\circ} \mathrm{C}$ for four days. Mycelial plugs were obtained from the growing part of the fungus to obtain a pure culture.

The fungicides were mixed with PDA culture medium at the indicated concentrations (Table 1). Each treatment 
consisted of four $8.4 \mathrm{~cm}$ Petri dishes which were filled with $25 \mathrm{cc}$ of the mix solution. 0.6-cm-diameter mycelium plugs of $B$. cinerea were placed in the central zone of each petri dish. Treatments were incubated at $25 \pm 1 \mathrm{C}^{\circ}$. Mycelial growth was measured every $24 \mathrm{~h}$ until the control covered the surface of the medium.

The percentage of Inhibition mycelial growth was determined by the following equation:

$$
I M G=\frac{m g c-m g f}{m g c} \times 100
$$

$I M G=$ Inhibition of Mycelial Growth

$m g f=$ Mycelial growth with fungicide treatment

$m g c=$ Mycelial growth with the control or unsprayed treatment

\section{Evaluation of conidial germination}

To evaluate the effect of fungicides on conidial germination, two tests were established. In the first test, a solution of conidia at a concentration of $1 \times 10^{6}$ conidia/ $\mathrm{mL}$ was prepared. A drop of the obtained concentration $(0.2 \mathrm{ml})$ was placed on the slide. Subsequently, a drop of fungicide solution with the established dose was placed on top of the first drop. Four repetitions were established per treatment. These slides were placed in humid chambers at room temperature to conserve moisture. Germination was defined when the germ tube reached half the length of the conidium (Jackson et al., 1985). This test was evaluated every $4 \mathrm{~h}$ for a period of $24 \mathrm{~h}$, taking 100 conidia per repetition.

In the second test, a concentration of 125 conidia/ $\mathrm{mL}$ was prepared. These conidia were placed in Petri dishes with PDA poisoned except for the control. The conidia were scattered with the help of Drigalski triangle throughout the culture medium. Finally, these conidia were incubated at $25 \mathrm{C}^{\circ}+/-1$.

The percentage of Inhibition of conidial germination was determined by the following equation:

$$
\text { Eq. (2) }
$$

$$
I C G=\frac{G C-G f}{G C} \times 100
$$

$I C G=$ Inhibition of conidial germination

$G f=$ germination with the fungicide treatment

$G c=$ germination with the control or unsprayed treatment

\section{Field phase}

\section{Features of the experimental field}

The field trial was carried out in Huaral, Lima. The crop had been established approximately two and a half months before the installation of the experiment. The strawberry cultivar was Aromas. The field was a furrow irrigation. The experiment was installed the beginning of flowering stage. By the time of installing the experiment, no application of fungicides had been sprayed. The field had disea-ses attacks in previous seasons. In addition, due to the high relative humidity, the field presented necessary conditions for the development of the pathogen. The experimental design was a Randomized Complete Block design (RCB). Four blocks and thirty-two plots were established (Figure 1). The field showed an average temperature of $15.65^{\circ}$ $\mathrm{C}$ with a maximum of $25^{\circ} \mathrm{C}$ and a minimum of $11.9^{\circ}$ C. Finally, the average relative humidity of the field was 94.94\% during the trial.

\section{Plant Categorization}

Due to variability of plants within the plots, a categorization was established. To obtain a more precise weight and number of fruits in the evaluations. The plants were separated into 4 categories due to their size: Category 1 (Large), Category 2 (Medium), Category 3 (Small) Category 4 (Very small). Because the size of the plants had a direct effect on production, plants of Category 4 were excluded. These plants did not show a normal development. They had growth, flowering, and production problems.

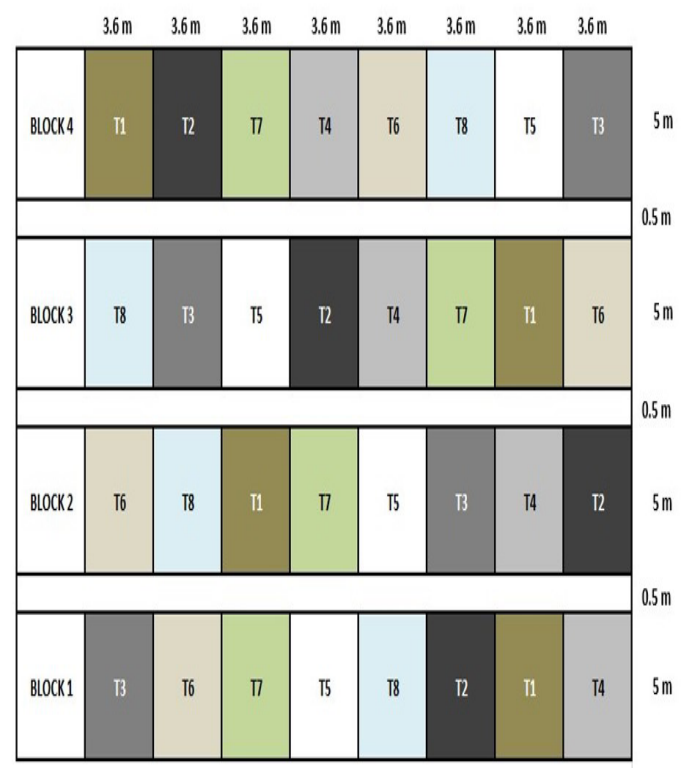

Figure 1A.

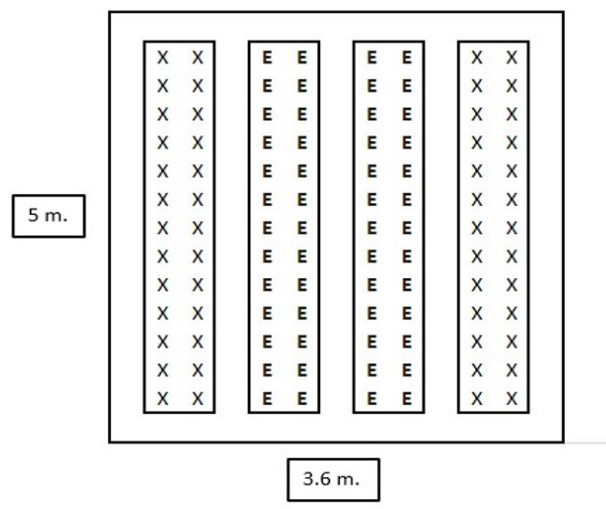

Figure 1B

Figure 1A Layout of plots in the experimental area; Figure 1B. Distribution of assessed plants (E) and no-assessed plants $(\mathrm{X})$ in the plot. 


\section{Treatment Application}

Chemical fungicides were sprayed every other week while biological fungicides were sprayed weekly. In total, 6 applications of chemical fungicides and 3 applications of biological products were established. A 20L-capacity backpack was used. Each fungicide treatment was applied with its respective commercial dose. All treatments were mixed with Kinetic (adjuvant) at $0.0125 \%$ concentration. The a-pplications presented an average water expenditure of $550 \mathrm{~L} / \mathrm{ha}$. The first application started once the presence of the pathogen was confirmed.

\section{Assessment - Evaluation}

The total number of evaluations (harvests) was twelve. They were conducted twice a week (Monday and Friday). The evaluation was carried out in the two central rows of each plot. Every plot consisted of four rows, each row was formed by 2-line of strawberry plants (double row so-wing). (Figure 1). The fruits were evaluated in three cate-gories. i) Fruits of the First Category: Fruits of great size and good conformation $(>3.5 \mathrm{~cm})$. ii) Fruits of Second Category: Small fruits and/or fruits with some deformations $(<3.5$ $\mathrm{cm})$ iii) Fruits with the presence of Botrytis cinerea: Fruits with symptoms or signs of the pathogen. Data of yield and number of fruits were taken in every plot. The fruits of the first and second category were classified according to the commercial standards required by the bu-yer. Once harvested, the fruits were counted, weighed and separated by the aforementioned categories.

\section{Area Under Disease Progress Curve (AUDPC)}

The area under the disease progress curve (AUDPC) was calculated through the number of fruits with the presence of Botrytis cinerea. The incidence of each harvest was obtained by dividing the number of strawberry fruits accumulated at the moment of the harvest between the number of fruits obtained during the development of the research (Total number of fruits with BC from Harvest 1 to 12 )

This value was obtained by means of the following equation:

$$
A U D P C=\sum_{i}^{n-1}\left(y_{i}+y_{i+1} / 2\right) /\left(t_{i+1}-t_{i}\right)
$$

$\Sigma=$ Summation of $\mathrm{n}$ observations

$\mathrm{n}=\mathrm{I}$-th observation

$\mathrm{yi}=$ Proportion of disease (incidence) affected in the i-th observation.

$\mathrm{ti}=$ time (days) after the $\mathrm{i}$-th observation

\section{Adjusting yield and number of fruits.}

To estimate the real values in each category, the data obtained by the central rows were adjusted by the following procedure: The weight and the number of fruits obtained by evaluation (2-rows area) were divided among the number of plants considered productive.
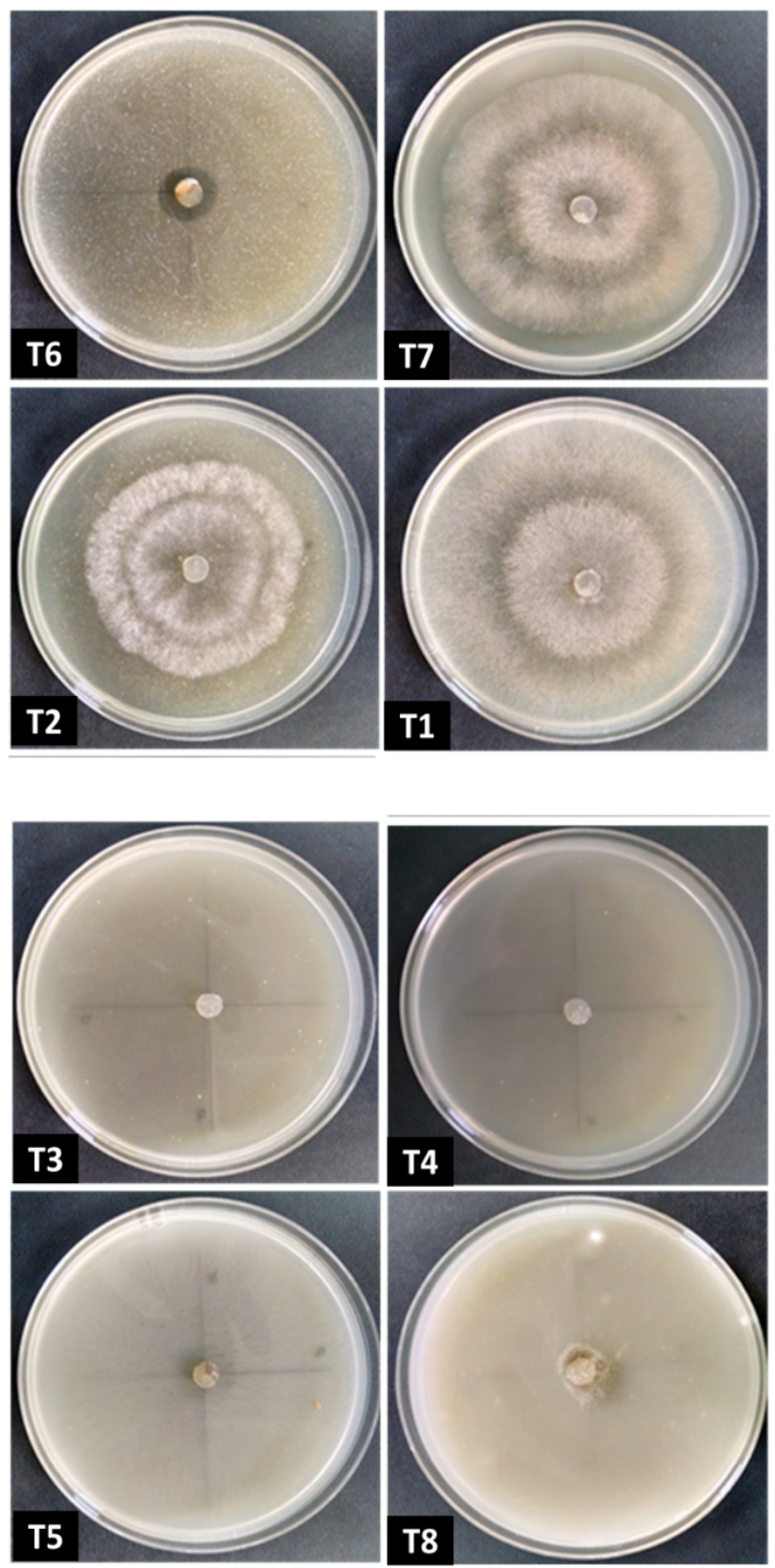

Figure 2. Effect on mycelial growth of chemical and biological fungicides using the poisoned culture technique 4 days after placing in the Petri dish. Mycelial disc of Botrytis cinerea was used as inoculum.

This procedure was necessary to obtain the average weight (gr) and number adjusted of fruits per plant. Then, to obtain the yield per plot the adjusted average weight obtained per plant was multiplied by the average number of plants in the central furrows (64 plants). Finally, to calculate the yield and the number of fruits per ha. The values were taken from the area of the two central furrows $\left(9 \mathrm{~m}^{2}\right)$.

\section{Statistical Analisys}

The data obtained were evaluated by using the statistical software SAS 9.0 (Statistical analysis system) $(\mathrm{P} \leq 0.05)$. 
Analysis of variance (ANOVA) was performed under a Completely Randomized Design (CRD) in the laboratory phase and a Randomized Complete Block design (RCB) in the field phase. In all cases, four repetitions were established. The statistical analysis of means was by the Tukey test $(\mathrm{P} \leq 0.05)$.

\section{Results and Discussions \\ Laboratory Phase}

Effect of fungicides on mycelial growth

The results are shown in Table 2 . The analysis of variance in mycelial growth showed significant differences $(\mathrm{P} \leq 0.05)$
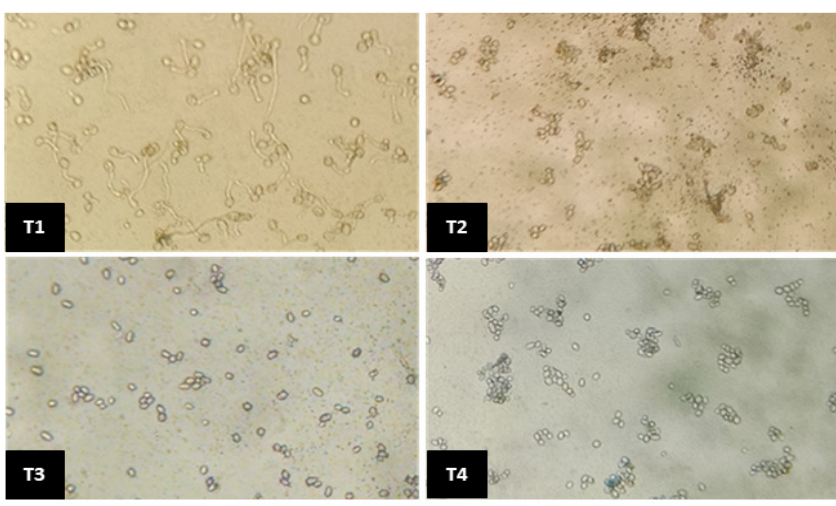

individually by Elad et al. (2007); Vidhyasekaran (2004); Veloukas and Karaoglanidis (2012); Vitale et al. (2016) and Nguyen et al. (2005).

\section{Effect of fungicides on conidial germination}

The germination results of conidia in sterile water and PDA medium are shown in Table 2. These results showed highly significant differences $(\mathrm{P} \leq 0.05)$ after 24 hours in the percentage of germination. Initial germination could be observed after 4 hours coinciding by La Torre \& Rioja (2002). In these two in vitro tests, the active ingredients that showed an inhibition greater than $90 \%$ were the treatments Pyrimethanil + Fluopyram, Pyrimethanil, Fenhexamid

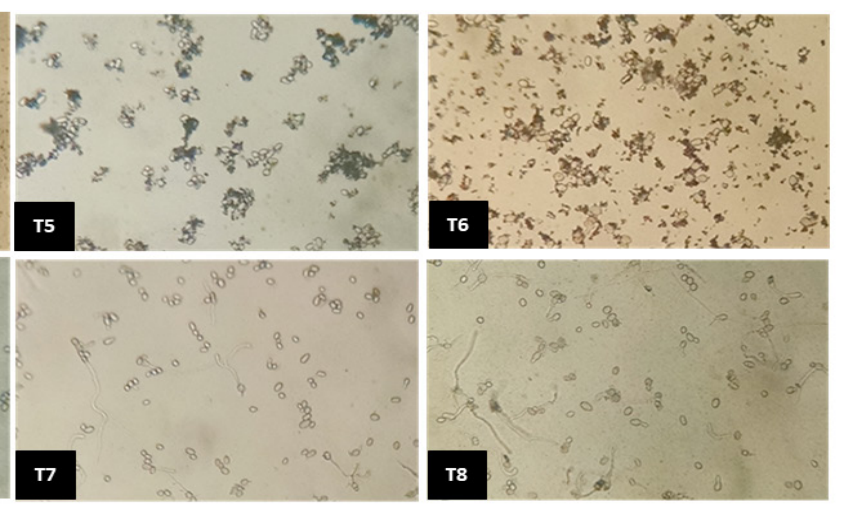

Figure 3. Effect of chemical and biological fungicides on conidial germination after 24 hours. Conidial solution on water was used. La Molina, 2015..

at 4 days after inoculation with the mycelial plug. At that moment the control occupied the entire area of the culture medium, coinciding with that reported by PlascenciaTenorio et al. (2012). Of all evaluated treatments, and Trifloxystrobin as chemical fungicides, and Bacillus subtilis as a biological fungicide. These former treatments did not show statistical differences among them $(\mathrm{P}>0.05)$ (Table 2, Figure 3). These results coincide with Rebollar

Table 2. Effect of chemical and biological fungicides in in vitro tests for mycelial growth and conidial germination of Botrytis cinerea.

\begin{tabular}{|c|c|c|c|c|c|c|c|c|}
\hline \multicolumn{2}{|c|}{$\begin{array}{l}\mathrm{N}^{\circ} \\
\text { Fungicide a.i. }\end{array}$} & \multirow[t]{2}{*}{ Product } & \multicolumn{2}{|c|}{ Mycelial Growth } & \multicolumn{2}{|c|}{$\begin{array}{l}\text { Conidial Germination - } \\
\text { Steril water }\end{array}$} & \multicolumn{2}{|c|}{$\begin{array}{l}\text { Conidial Germination - } \\
\text { PDA }\end{array}$} \\
\hline & & & $\begin{array}{l}\text { Diam. } \\
\text { Growth }\end{array}$ & $\begin{array}{l}\text { PIMG } \\
(\%)\end{array}$ & $\begin{array}{l}\text { Germination } \\
(\%)\end{array}$ & PICG (\%) & CFU & $\begin{array}{l}\text { PICG } \\
(\%)\end{array}$ \\
\hline 1 & none & Unsprayed Control & $8.40 \mathrm{a}$ & 0.00 & $37.75 \mathrm{a}$ & 0.00 & $137.5 \mathrm{a}$ & 0.00 \\
\hline 2 & Trifloxystrobin & Flint $50 \mathrm{WG}$ & $5.68 \mathrm{c}$ & 32.14 & $0.75 \mathrm{dc}$ & 98.01 & $1.75 \mathrm{~d}$ & 98.73 \\
\hline 3 & Pyrimethanil + Fluopyram & Luna Tranquility $500 \mathrm{SC}$ & $0.00 \mathrm{e}$ & 100.00 & $0.00 \mathrm{~d}$ & 100.00 & $1.50 \mathrm{~d}$ & 98.91 \\
\hline 4 & Pyrimethanil & Scala $40 \mathrm{SC}$ & $0.00 \mathrm{e}$ & 100.00 & $0.00 \mathrm{~d}$ & 100.00 & $2.00 \mathrm{~d}$ & 98.55 \\
\hline 5 & Fenhexamid & Teldor SC & $0.00 \mathrm{e}$ & 100.00 & $0.50 \mathrm{dc}$ & 98.68 & $1.75 \mathrm{~d}$ & 98.73 \\
\hline 6 & Bacillus subtilis Strain QST713 & Serenade ASO & $0.00 \mathrm{e}$ & 100.00 & $2.25 \mathrm{c}$ & 94.04 & $5.25 \mathrm{~cd}$ & 96.18 \\
\hline 7 & Bacillus pumilus Strain QST2808 & Sonata ASO & $6.89 \mathrm{~b}$ & 18.50 & $31.25 \mathrm{a}$ & 17.22 & $56.00 \mathrm{~b}$ & 59.27 \\
\hline \multirow[t]{2}{*}{8} & Carbendazim & Fordazim $5 \mathrm{FW}$ & $1.60 \mathrm{~d}$ & 80.95 & $22.75 \mathrm{~b}$ & 39.74 & $16.50 \mathrm{c}$ & 88.00 \\
\hline & C.V.(\%) & & 3.5 & & 14.8 & & 19.82 & \\
\hline
\end{tabular}

Means with the same letters do not present statistical differences $(\alpha=0.05)$, PIMG: Percentage of inhibition of mycelial growth PICG: Percentage of inhibition of conidial germination, CFU: Colony Forming Units

those that presented an excellent control in the mycelial development of Botrytis cinerea were Fenhexamid, Bacillus subtilis strain QST713, Pyrimethanil + Fluopyram and Pyrimethanil (Table 2, Figure 2). The effect of these active ingredients on Botrytis cinerea has also been mentioned
(2011), Elad et al. (2007), Veloukas and Karaoglanidis (2012) and Lisboa (2003) who evaluated these active ingredients at this level. Regarding Trifloxystrobin treatment, its good control at this level coincides with Myresiotis et al. (2007) who also states that this type 
of fungicide does not show a dominant effect on the inhibition during the mycelium stage. Additionally, Elad et al. (2007), mentioned that this behavior could be related to the fact that terminal oxidase (AOX), a component present in the mitochondria of Botrytis cinerea, allows the flow of electrons avoiding the blocking of cytochrome metabolism caused by strobilurins. However, the chemical fungicide that showed the lowest control in both tests was Carbendazim coinciding with Elad et al. (2007) who mentioned that this class of fungicides does not prevent the germination of conidia in Botrytis cinerea.

\section{Field Phase}

\section{Area Under Disease Progress Curve (AUDPC)}

According to the analysis of variance in the AUDPC during the experiment, highly significant differences between treatments were found $(\mathrm{P} \leq 0.05)$. Bacillus subtilis, Fenhexamid, Pyrimethanil, Pyrimethanil + Fluopyram and Trifloxystrobin obtained 131.80, 123.48, 119.58, 107.84 and 95.38 respectively, no showing significant differences between them $(\mathrm{P}>0.05)$ (Table 3$)$. These treatments had significant differences $(\mathrm{P} \leq 0.05)$ with the control treatment, whose value was the highest (202.65). Finally, these results coincide with Rosslenbroich and Stuebler (2000) who mentioned the effect of some these active ingredients against BC (Table 3).

\section{Effect of fungicides on fruit yield}

Highly significant differences were found in the analysis of variance with the Category-1 fruit $(\mathrm{P} \leq 0.05)$. The treatments with the highest value were treated with Pyrimethanil and Pyrimethanil + Fluopyram whose values were 7,685.2 and 7,679.0 $\mathrm{Kg}$ /ha respectively. These treatments did not present statistical differences between them $(\mathrm{P}>0.05)$. These results coincide with Wedge (2007) who mentioned the e-ffect of Pyrimethanil in the control of BC in Strawberry cv. Camarosa. In addition, Bacillus subtilis showed the highest value of the group of biological fungicides in the performance of Category 1. Neither the group of chemical treatments nor control presented significant differences with this biological treatment $(\mathrm{P}>0.05)$. Finally, no significant differences were found

Table 3. Effect of chemical and biological fungicides on strawberry cv. Aromas Yield under field conditions.

\begin{tabular}{cccccc}
\hline $\mathrm{N}^{\circ}$ & i.a. & Cat. 1 & Cat. 2 & Infected fruit & *Infected fruit (\%) \\
\hline 1 & none & $5034.4 \mathrm{~b}$ & $1347.7 \mathrm{a}$ & $391.8 \mathrm{a}$ & $5.97 \mathrm{a}$ \\
2 & Trifloxystrobin & $6615.8 \mathrm{ab}$ & $1326.5 \mathrm{a}$ & $152.6 \mathrm{bc}$ & $1.88 \mathrm{bc}$ \\
3 & Pyrimethanil + Fluopyram & $7679.0 \mathrm{a}$ & $1227.5 \mathrm{a}$ & $152.7 \mathrm{bc}$ & $1.69 \mathrm{c}$ \\
4 & Pyrimethanil & $7685.2 \mathrm{a}$ & $1484.1 \mathrm{a}$ & $119.4 \mathrm{c}$ & $1.28 \mathrm{c}$ \\
5 & Fenhexamid & $5924.0 \mathrm{ab}$ & $1350.2 \mathrm{a}$ & $136.0 \mathrm{c}$ & $1.85 \mathrm{bc}$ \\
6 & Bacillus subtilis Strain QST713 & $6401.1 \mathrm{ab}$ & $1347.3 \mathrm{a}$ & $321.5 \mathrm{a}$ & $3.96 \mathrm{ab}$ \\
7 & Bacillus pumilus Strain QST2808 & $5424.7 \mathrm{~b}$ & $1279.9 \mathrm{a}$ & $271.3 \mathrm{ab}$ & $3.97 \mathrm{ab}$ \\
8 & Carbendazim & $6461.4 \mathrm{ab}$ & $1327.7 \mathrm{a}$ & $398.0 \mathrm{a}$ & $4.90 \mathrm{a}$ \\
\hline
\end{tabular}

Means with the same letters do not present statistical differences $(\alpha=0.05)$

Cat. 1: Category 1

Cat. 2: category 2

* Percentage of the yield of infected fruit in comparison with the total yield during the experiment (Cat.1+Cat.2+Infected fruit)

Table 4. Effect of chemical and biological fungicides on the number of Strawberry cv. Aromas and Area under the Botrytis cinerea Progress Curve in field conditions

\begin{tabular}{|c|c|c|c|c|c|c|}
\hline \multirow[b]{2}{*}{$\mathrm{N}^{\circ}$} & \multirow[b]{2}{*}{ ia } & \multicolumn{4}{|c|}{ Number of fruits } & \multirow[t]{2}{*}{$\mathrm{ABCPE}$} \\
\hline & & Category 1 & Category 2 & Infected Fruits & 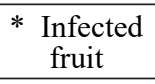 & \\
\hline 1 & none & $270932.0 \mathrm{a}$ & $164662.0 \mathrm{a}$ & $52117.0 \mathrm{a}$ & $10.78 \mathrm{a}$ & $202.65 \mathrm{a}$ \\
\hline 2 & Trifloxystrobin & $298616.0 \mathrm{a}$ & $154150.0 \mathrm{a}$ & $22139.0 \mathrm{c}$ & $4.72 \mathrm{~d}$ & $95.38 \mathrm{c}$ \\
\hline 3 & Pyrimethanil + Fluopyram & $298185.0 \mathrm{a}$ & $145664.0 \mathrm{a}$ & $24487.0 \mathrm{c}$ & $5.17 \mathrm{~d}$ & $107.84 \mathrm{bc}$ \\
\hline 4 & Pyrimethanil & $325907.0 \mathrm{a}$ & $176047.0 \mathrm{a}$ & $27595.0 \mathrm{c}$ & $5.24 \mathrm{~d}$ & $119.58 \mathrm{bc}$ \\
\hline 5 & Fenhexamid & $268450.0 \mathrm{a}$ & $167682.0 \mathrm{a}$ & $25996.0 \mathrm{c}$ & $5.63 \mathrm{dc}$ & $123.48 \mathrm{bc}$ \\
\hline 6 & Bacillus subtilis Strain QST713 & $306820.0 \mathrm{a}$ & $165800.0 \mathrm{a}$ & $39750.0 \mathrm{~b}$ & $7.81 \mathrm{bc}$ & $131.80 \mathrm{bc}$ \\
\hline 7 & Bacillus pumilus Strain QST2808 & $259907.0 \mathrm{a}$ & $155061.0 \mathrm{a}$ & $41581.0 \mathrm{ab}$ & $9.14 \mathrm{ab}$ & $153.77 \mathrm{ab}$ \\
\hline 8 & Carbendazim & $319190.0 \mathrm{a}$ & $165016.0 \mathrm{a}$ & $43423.0 \mathrm{ab}$ & $8.28 \mathrm{ab}$ & $151.67 \mathrm{ab}$ \\
\hline \multicolumn{2}{|r|}{ C.V.(\%) } & 12.05 & 11.35 & 13.31 & 15.20 & 16.07 \\
\hline
\end{tabular}

Means with the same letters do not present statistical differences $(\alpha=0.05)$

$*$ Percentage of number of infected fruit in comparison with the total number during the experiment (Cat. $1+$ Cat. $2+$ Infected fruit) 
with Category-2 fruit $(\mathrm{P}>0.05)$.

Regarding the number of fruits infected with Botrytis cinerea, highly significant differences $(\mathrm{P} \leq 0.05)$ were found in this category. The treatments Pyrimethanil + Fluopyram with 152.7, Trifloxystrobin with $152.6 \mathrm{Kg} /$ ha, Fenhexamid with $136 \mathrm{Kg} / \mathrm{ha}$ and Pyrimethanil with $119.4 \mathrm{Kg} /$ ha presented the lowest values. These treatments did not present significant differences between them. On the other hand, Carbendazim, the control, Bacillus subtilis strain QST713, Bacillus pumilus strain QST2808 presented the highest values in the yield of fruits infected with Botrytis cinerea with 398, 391.8, 321.5 and $271.3 \mathrm{Kg} /$ ha respectively.

The control treatment presented the highest fruit percentage of $\mathrm{BC}$ with a value of $5.97 \%$. The treatments that presented significant differences $(\mathrm{P} \leq 0.05)$ at this level with the control treatment were Trifloxystrobin with $1.88 \%$, Fenhexamid with $1.85 \%$, Pyrimethanil + Fluopyram with $1.69 \%$ and Pyrimethanil with $1.28 \%$. They did not present statistical differences between them $(\mathrm{P}>0.05)$ (Table 3$)$.

\section{Effect of fungicides on the number of fruits.}

The results did not show significant differences in Category 1 and Category $2(\mathrm{P}>0.05)$ (Table 4). On the other hand, the analysis of variance in the number of fruits with the presence of Botrytis cinerea obtained highly significant differences $(\mathrm{P} \leq 0.05)$. The control treatment presented the highest value, 52117 fruits/ha. The lowest values were obtained with the treatments Pyrimethanil, Fenhexamid, Pyrimethanil and Trifloxystrobin whose values were 27,$595 ; 25,966 ; 24,487 ; 22,139$ fruits/ha respectively. They did not show statistical differences between them $(\mathrm{P}>0.05)$.

The analysis of variance showed highly significant differences in the percentage of fruits with the presence of Botrytis cinerea $(\mathrm{P} \leq 0.05)$. In this analysis, the control treatment obtained the highest percentage with a value of $10.78 \%$. On the other hand, the treatments that presented the lowest values were: Fenhexamid with $5.63 \%$, Pyrimethanil with $5.24 \%$, Pyrimethanil + Fluopyram with $5.17 \%$ and Trifloxystrobin with $4.72 \%$. These treatments did not show significant differences between them $(\mathrm{P}>0.05)$. The effect of Fenhexamid on the incidence of affected fruits coincide with Sallato et al. (2007) and Bay et al. (2010), who found low values of the disease after applications of Fenhexamid. However, Veloukas and Karaoglanidis (2012) found good control of Fluopyram against Botrytis cinerea in strawberry fruits cv. Camarosa. Furthermore, Wilcox (2007) observed a good effect of Trifloxystrobin against this pathogen. Regarding Biological fungicide Bacillus subtilis, Elad et al. (2007) and Lisboa (2003) stated that this biological fungicide has an effect against Botrytis cinerea.

\section{Conclusion}

The fungicides that showed high mycelial inhibition were Pyrimethanil, Pyrimethanil + Fluopyram, Fenhexamid and the biological fungicide Bacillus subtilis strain QST713. Regarding conidial inhibition, the fungicides described above and the fungicide Trifloxystrobin showed excellent control at this level. Under field conditions, the chemical fungicides Trifloxystrobin, Fenhexamid, Fluopyram + Pyrimethanil, pyrimethanil and the biological fungicide Bacillus subtilis showed a high activity against Botrytis cinerea.

This study, which show the performance of chemical and biological fungicides, is a baseline to help strawberry growers to develop effective fungicide spray programs, for gray mold in agreement with Integrated Pest Management (IPM).

\section{Literature cited}

Álvarez, T. (2013). Biocontrol de Botrytis cinerea a partir de extractos fenólicos de Fresa. Thesis to opt for the degree of Maestro en Ciencia en Producción Agrícola Sustentable, Instituto Politécnico Nacional, México. http://repositoriodigital.ipn.mx/ handle/123456789/16418

Bay, I., Eynard, J. and Gubler, W. (2010). Evaluation of fungicide programs for management of Botrytis bunch rot of grapes: 2010 field trial. [on line] California: University of California, Davis. Retrieved from: https:// escholarship.org/uc/item/8gs9k471 [2017, march 12]

Benito, E.P., Arranz, M. and Eslava A. (2000). Factores de patogenicidad de Botrytis cinerea. Revista Iberoamericana de Micología 17, S43-S46.

Cano, A. (2013). Estrategias biológicas para el manejo de enfermedades en el cultivo de fresa (Fragaria spp). Revista Colombiana de Ciencias Hortícolas, 7(2), 263276.

Chaves, N. and Wang, A. (2004). Combate del Moho gris (Botrytis cinerea) de la Fresa mediante Gliocladium roseum. Agronomía Costarricense, 28(2), 73-85.

Elad, Y., Williamsom, B., Tudzynski, P. and Denle, N. (2007). Botrytis: Biology, pathology and control. Dordretcht, The Netherlands: Ed. Springer.

Espinosa, M. (2006). Estudio de la variabilidad genética y organización cromosómica en el hongo fitopatógeno Botrytis cinerea. Thesis to opt for the degree of Doctor. Universidad de Cádiz, España.

Fernández-Larrea V. O. (2001). Microorganismos antagonistas para el control fitosanitario. Manejo Integrado de Plagas (Costa Rica), 62, 96-100

Genoscope. (2005). Sequencing projects of Botrytis cinerea. Estimated losses for vineyards in France amount to $15-40 \%$ of the harvest, depending on climatic conditions.

Ghorbani, R., Wilcockson, S., Koocheki, A. and Leifert, C. (2008). Soil management for sustainable crop disease control: a review. Journal Environmental Chemistry Letters, 6, 149-162

Jackson, C.W., Heale, J.B., and Hall, R.A. (1985). Traits associated with virulence to the aphid Macrosiphoniella sanborni in eighteen isolates of Verticillium lecanii. 
Annuals of Applied Biology, 106(1), 39-48. https://doi. org/10.1111/j.1744-7348.1985.tb03092.x

Koike, S.T., Browne, G.T. and Gordon, T.R. (2016). Diseases. In UC IPM Pest Management Guidelines: Strawberry. (p.116). California: UC Statewide IPM program.

La Torre, B.A. and Rioja M.E. (2002). Efecto de la temperatura y de la humedad relativa sobre la germinación de conidias de Botrytis cinerea. Revista latinoamericana de ciencias de la agricultura, 29(2), 67-72.

Lisboa, M. (2003). Efectividad de Bacillus subtilis y de una cepa nativa de Trichoderma harzianum sobre la incidencia y severidad de pudrición gris (Botrytis cinerea) en vid vinifera. Thesis to opt for the degree of Ingeniero Agrónomo. Universidad de Talca, Chile. http://dspace.utalca.cl/handle/1950/919

Molina, G., Zaldúa, S., González, G. and Sanfuentes, E. (2006). Selección de hongos antagonistas para el control biológico de Botrytis cinerea en viveros forestales en Chile. Bosque, 27(2), 126-134

Myresiotis, C.K., Karaoglanidis, G.S. and TzavellaKlonaris, K. (2007). Resistance of Botrytis cinerea isolates from vegetables crops to anilipyrimidine, phenylpyrrole, hydroxyanilide, benzimidazole, and dicarboximide fungicides. Plant Disease, 91(4), 407413. https://doi.org/10.1094/PDIS-91-4-0407

Nguyen, H., Soon-Ok, O., Gyoung, K., Jae-Seoun, H., JaeSeoun, H. and Young, K. (2005). Bacillus subtilis S10210 as a Biocontrol agent against Botrytis cinerea in Strawberries. The Plant Pathology Journal, 21(1), 59 - 63. http://dx.doi.org/10.5423/PPJ.2005.21.1.059

Plascencia-Tenorio, R., Olalde-Portugal, V., MenaViolante, H.G., Ceja-Torres, F., Venegas-Gonzales, J., Oyoque-Salcedo, G. and Angoa-Perez. M.V. (2012). Antagonismo in vitro de aislados bacterianos de fresa comercial y silvestre vs Botrytis cinerea y Rhizopus stolonifer. Ra Ximhai, 8(3), 103-110.

Rossleinbroich, H.J. and Stuebler, D. (2000). Botrytis cinerea-History of chemical control and novel fungicide for its management. Crop Protection, 19(8), 557-561. https://doi.org/10.1016/S0261-2194(00)00072-7

Sallato. B.V., Torres, R., Zoffoli, P. and La Torre, B.A. (2007). Effect of boscalid on postharvest decay of strawberry caused by Botrytis cinerea and Rhizopus stolonifer. Spanish Journal of Agriculture Research, 5(1), 67-78. DOI: $10.5424 / \mathrm{sjar} / 2007051-224$

Rebollar, A. (2011). Manejo del Mildiu y el Moho Gris de la zarzamora en Michoacán (1 ed.) México: Universidad Autónoma Chapingo.

Veloukas, T. and Karaoglanidis. G.S. (2012). Biological activity of the succinate dehydrogenase inhibitor fluopyram against Botrytis cinerea and fungal baseline sensitivity. Pest Management Science, 68(6), 858-864. https://doi.org/10.1002/ps.3241
Vidhyasekaran, P. (2004). Concise encyclopedia of Plant Pathology. New York, USA: The Haworth Press, Inc.

Vitale, A., Panebianco, A. and Polizzi, G. (2016). Baseline sensitivity and efficacy of fluopyram against Botrytis cinerea from table grape in Italy. Annals of Applied Biology, 169(1), 36-45. https://doi.org/10.1111/ aab.12277

Wedge, D., Smith, B., Quebedeaux, J. and Constantin, R. (2007). Fungicide Management strategies for control of strawberry fruit rot diseases in Lousiana and Mississippi. Crop Protection, 26(9), 1449-1458. https://doi.org/10.1016/j.cropro.2006.12.007 